\title{
Analysing Temporal and Spatial Changes in Land Cover: the Case of Drahna Forest Subdistrict Directorate
}

\author{
Sinan $\operatorname{KAPTAN}^{1 *}$, Ali DURKAYA ${ }^{1} \mathbb{0}$ \\ ${ }^{1}$ Bartın University, Department of Forest Engineering, Bartın, TURKEY \\ *Corresponding author: skaptan@bartin.edu.tr
}

Received Date: 31.08.2018

Accepted Date: 31.12 .2018

\begin{abstract}
Aim of study: In this study, changes in land cover and land use from designing forest management plans within a plan unit up until today in the field of study are analysed under various categories.

Field of study: Drahna Forest Subdistrict Directorate (FSD) under Ulus Forest Operation Directorate (FOD) of Zonguldak Regional Directorate of Forestry (RDF) was selected as the field of this study.

Material and Method: Forest management plans and forest cover type maps for the related plan unit were utilized in the study. Forest cover type maps for the years 1967-1986 and 1986-2005 were digitized by using Geographical Information System tool ArcGIS version 10.4, whereas forest cover type map for the years 2006-2024 was obtained digitized from the relevant authority.

Results: It was found that there was an increase of 227.6 ha in forest land in addition to a decrease of 227.6 ha in non-forest land between 1967 and 2006. It was also determined that there was a decrease of $2,295.33$ ha in sparse forest land (with less than $10 \%$ canopy closure) whereas an increase of 2,523 ha in productive forest land (canopy closure above 11\%). Further, a decrease of 369.91 ha in agricultural land in contrast with an increase of 36.69 ha in treeless forest land (TFL) and of 105.62 ha in settlement land were observed as well in non-forest lands.

Emphasis of study: Within a period of 40 years between 1967 and 2006, immigration led to decreases in agricultural land and increases in forest land within the field of this study.

Keywords: Land use, land cover, geographical information systems, forest management, temporal and spatial change

\section{Arazi Örtüsünde Meydana Gelen Zamansal ve Mekânsal Değişimlerin Incelenmesi: Drahna Orman İşletme Şefliği Örneği}

Öz

Çalışmanın amacı: Bu çalışmada plan ünitesi içerisinde orman amenajman planlarının yapımından günümüze kadar çalışma alanında yaşanan arazi örtüsü ve kullanımında yaşanan değişimler çeşitli kategoriler altında incelenmiştir.

Çalışma alanı: Çalışma alanı olarak Zonguldak Orman Bölge Müdürlüğü (OBM), Ulus Orman İşletme Müdürlüğü (OIM)'ne bağlı Drahna Orman İşletme Şefliği (Oİ̧̧) seçilmiştir.

Materyal ve Yöntem: Çalş̧̧ada ilgili plan ünitesine ait orman amenajman planları ve meşcere tipleri haritalarından yararlanılmıştır. Coğrafi Bilgi Sistemleri araçlarından olan ArcGIS sürüm 10.4 kullanılarak 1967-1986 ve 1986-2005 yıllarına ait meşcere tipleri haritaları sayısallaştırılmış, 2006-2024 yılı meşcere tipleri haritası ise sayısal haliyle ilgili kurumdan temin edilmiştir.

Sonuçlar: 1967 yılından 2006'ya kadar orman alanlarında 227.6 ha artış, orman dışı alanlarda ise 227.6 ha bir azalış olduğu tespit edilmiştir. Orman alanlarını oluşturan boşluklu kapalı orman alanında 2,295.33 ha azalma görülürken normal kapalı orman alanında 2,523 ha artıs olduğu belirlenmiştir. Orman dış1 alanlardan ziraat alanlarında 369.91 ha azalma, orman toprağında (OT) 36.69 ha ve iskân alanında ise 105.62 ha artış olduğu tespit edilmiştir.

Araştırma vurguları: 1967 'den 2006'ya kadarki 40 yıllık süre içerisinde çalışma alanı içerisinde yaşanan göç özellikle ziraat alanlarının azalmasına, orman alanlarının artmasına sebep olmuştur.

Anahtar Kelimeler: Arazi kullanımı/Arazi örtüsü, coğrafi bilgi sistemleri, orman amenajmanı, zamansal/mekânsal Değişim

*A summary of this work was published in the 1st International and Vocational Studies Congress. (5-8 October 2017, Nevşehir) 


\section{Introduction}

Humankind is the most important living being in the world with its power to have positive or negative influences on the ecosystem since its first existence. Especially, humanity's impact on the forest ecosystem has shown and will continue to show itself in the course of time in various forms and severities, Again, humanity previously started to transform forest lands into other types of land use on grounds of cultivating, hunting, making primitive tools and equipment, and grazing (FAO, 2016). Rapid increase of human population and the arrival of industrial revolution led to the increase of pressure on forest ecosystems day by day. Supplying energy and raw materials through natural resources to factories, resulting land and water pollution, the increase in atmospheric $\mathrm{CO}_{2}$ emission due to the use of fossil fuels, and the decrease in forest lands due to misuse have all contributed to the outbreak of severe environmental problems such as global warming and climate change (Asan, 2017).

With the impact of environmental problems, levels of awareness and knowledge of people on natural resources increased while at the same time countries started to seek for solutions to environmental problems (Keleş, Bașkent \& Kadığulları, 2009). For this purpose, meetings were held and treaties were signed, bringing the understanding of sustainable forestry to the agenda. Meeting demands of societies, constraining $\mathrm{CO}_{2}$ that leads to global warming; managing soil, water, and air quality; protecting biological diversity defined as the entirety of ecosystem, species, genetics, and ecological process diversity; protecting, improving, expanding, tracking, and status-reporting forest ecosystems to fulfil international commitments have all come to existence.

Protecting habitats, balancing global carbon budgets, tracking variances in order to understand the role of forests in global warming have critical importance in sustainable resource management (Hayes and Cohen, 2007). For this reason, natural resource administrators, politicians, and academics request data about changes in land cover for the purpose of evaluating multiple emergent issues such as global climate change, carbon budgets, and biodiversity
(Dixon et al., 1994; DeFries, Field, Fung, Collatz \& Bounoua, 1999; Verbesselt, Hyndman, Newnhamn \& Culvenor, 2010). Such data can recently be obtained with a certain margin of error thanks to remote sensing geographical information systems (GIS).

The number of studies on temporal and spatial analyses, which is insufficient in Turkey compared to the world scale, is gradually increasing with contributions from researchers. Kadıoğulları and Başkent (2006) investigated changes in forest resources at İnayet and Yenice Forest Subdistrict Directorates of İnegöl Forest Operation Directorate through satellite images and forest cover type maps. According to the results of the study, it was determined that there was an increase in quality of forest resources by confirming increases in those of type 2 and 3 conopy closures as well as those in types a, ab, and cd development stages in the forest stands. Çakır et al., (2008) used forest cover type maps in order to investigate the change from 1971 to 2002, establishing that there was an increase in forest lands in their study on the province of İstanbul. Durkaya, Varol \& Durkaya (2014) observed Ardıç, Kumluca, and Sökü FSDs of Bartın FOD for changes in carbon stock amounts and land use within planning periods of 1967, 1985, and 2011. Durkaya, Varol \& Durkaya (2016) revealed changes in carbon stock capacities and land use within 4 planning periods of 1968, 1985, 2001, and 2011 at Arıt FSD. Özdemir and Özkan (2003), Sivrikaya et al. (2007), Kadıoğulları, Keleş, Başkent \& Günlü (2008), Keleş, Sivrikaya, Çakir, Başkent, \& Köse (2008), Günlü, Kadığulları, Keleş \& Başkent (2009), Karahalil, Kadiogullari, Başkent \& Köse (2009), Terzioğlu et al., (2010), Turan and Günlü (2010), Kadığulları (2012), Karaköse, Terzioğlu, Başkent \& Karahalil (2013), Kanja and Karahalil (2015), Yavuz and Vatandaşlar (2018) all conducted studies on temporal and spatial changes.

It is required to digitize stand data types and establish a temporal database to obtain rudimentary data (Kanja and Karahalil, 2015). The purpose of this study is to determine changes in forest and non-forest lands within a period of 40 years from 1967, the inception of planning period, to 2006, the up-to-date 
planning period, at Drahna FSD. Main resources of the study are constituted by forest management plans and forest cover type maps of the relevant plan unit.

Forest management plans, which are the assurance of the realization of sustainable forestry, are one of the most reliable resources in the field of forestry as they contain plenty of data on the relevant plan unit. The plans include plenty of data such as general area of the plan unit, forest and non-forest lands, management types, forest forms, stand types, tree species, development stages as well as stocks and their increase in density classes. General Directorate of Forestry (GDF) uses the information obtained from the forest management plans of the Department of Forest Management and Planning in forestry statistics published for the entire country as a general source. In most academic studies and other authorities related to forestry, forest management plans and maps are preferred as a source.

\section{Material and Methods \\ Study area}

Field of the study comprises of Drahna FSD under Ulus FOD of Zonguldak RDF. Whereas forest land in Turkey constitutes $28.6 \%$ of the territory with an approximate area of 22,342,935 ha, proportion of forest land under Zonguldak RDF to the entirety is $63.4 \%$. In light of this proportion, it can be said that Zonguldak RDF ranks second after that of Kastamonu among all RDFs in Turkey (GDF, 2016; Kaptan, 2018). Drahna FSD is geographically located within $41^{0} 35^{\prime} 43^{\prime \prime} \mathrm{N}$, $41^{\circ} 46^{\prime} 11^{\prime \prime} \mathrm{N}$ and $32^{\circ} 42^{\prime} 57^{\prime \prime} \mathrm{E}, 32^{0} 56^{\prime} 2^{\prime \prime} \mathrm{E}$ (Figure 1).

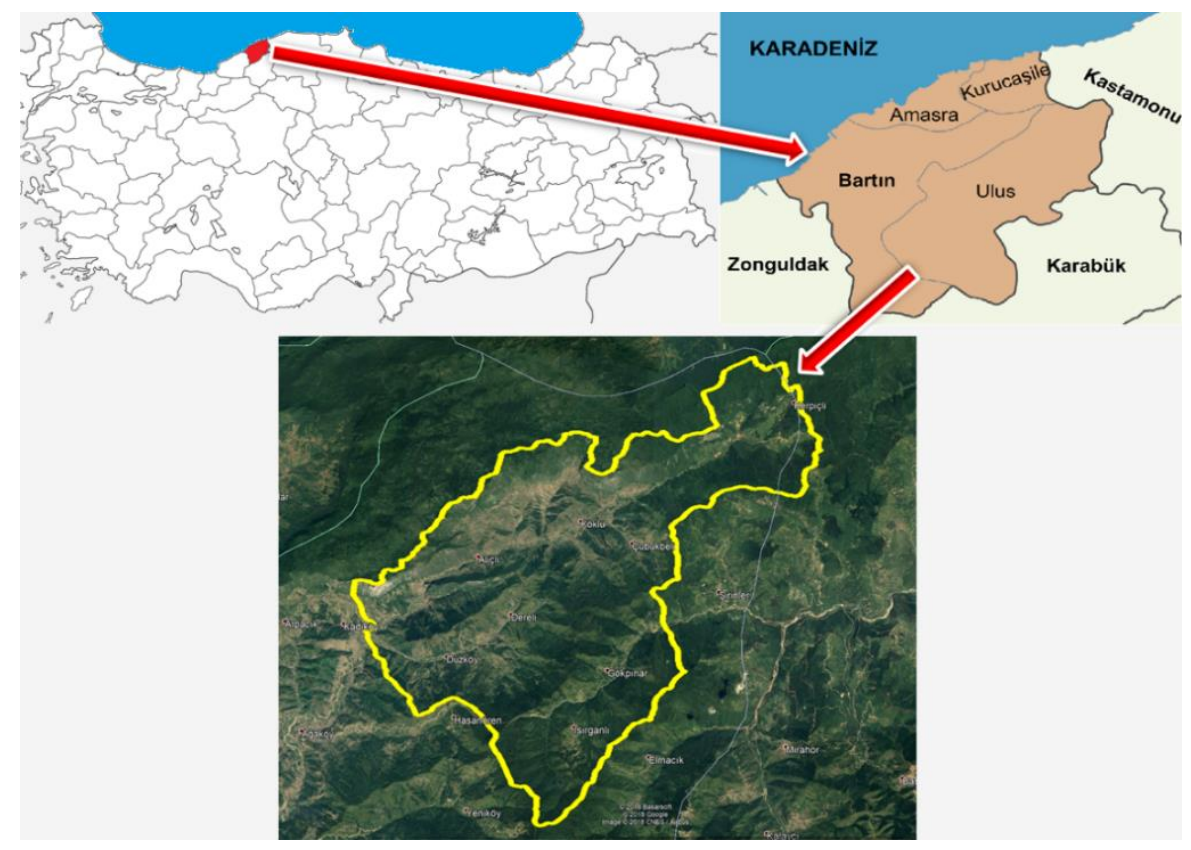

Figure 1. Location of Drahna Forest Subdistrict Directorate in Turkey

The area has an elevation ranging between $17 \%$ and $58 \%$. The plan unit was first designed on a series basis as Drahna, Merer, and Kokurdanlar Series between the years 1967-1986. Kokurdanlar Series was later reestablished as Akıncilar Subdistrict Directorate, and was included in "KastamonuBartın Küre Mountains National Park" established via Council of Ministers decision dated May 18th, 2000 (GDF, 2006). For this reason, Kokurdanlar Series was left out of the field of this study.

\section{Digitization and Classification}

In this study, three forest management plans and forest cover type maps for the period from 1967 to 2006 of the relevant subdistrict were used. Analyses to reveal the change, which is the aim of the study, were used Geographical Information System. First, 
non-digitized forest cover type maps of forest management plans for the years 1967-1986 and 1986-2005 were digitized with the help of ArcGIS. During digitization, map sections scaled to $1: 25,000$ were taken as basis and rectified before digitization and analyses. Digitized version of forest cover type maps for the 2006-2025 forest management plan was obtained from the relevant authority.

With the help of spatial inquiries carried out on digital maps, changes in land cover and use during the 40 years from 1967 to 2006 were examined. During the examination on land cover changes in the plan unit, forest lands were categorized as "regular" and "sparse", while the non-forest lands as settlement $(\mathrm{S})$, agricultural $(\mathrm{Ag})$ and treeless forest land (TFL). Moreover, areal changes in forest land were presented in stand types ( $a, b$, $\mathrm{c}, \mathrm{d}, \mathrm{e})$ indicating tree species and development stage, and in density types (3, 2, 1 , and sparse) indicating their density classes.

\section{Results}

\section{Areal Changes in Land Cover}

\section{Changes in Sparse Forest Land}

According to the results (Figure 2), it was found that 3,595.88 ha of sparse forest land recorded in 1967 decreased in the course of 20 years by $42 \%$ to $2,079.61$ ha in 1986 , and by $37 \%$ down to $1,300.55$ ha in 2006. Sparse forest land decreased by an approximate total of $64 \%(2,295.33 \mathrm{ha})$ in the course of 40 years between 1967 and 2006. Coppice forest land was categorised in the planning period of 1967-1986 as good (Cg), medium (Cm), and weak $(\mathrm{Cw})$, being considered as unproductive and non-reclaimable free fields (GDF, 1967). For this reason, coppice forest land was included in sparse forest land class in this study.

\section{Changes in Productive Forest Land}

In the guide of "Procedures and Principles of Regulating Ecosystem-based, Functional Forest Management Plans" numbered 299, stands with below $10 \%$ canopy closure are defined as sparse forests whereas stands with a canopy closure between $11 \%$ and $100 \%$ as productive forests (GDF, 2017a). Productive forest land was $4,893.34$ ha in 1967 , while in 1986 it increased by $28 \%$ to $6,276.47$ ha. Continuing this increase in 2006, the forest land reached 7,416.31 ha with an approximate increase of $18 \%$ (Figure 2). In a period of 40 years, productive forest land increased by $52 \%(2,522.87$ ha $)$.

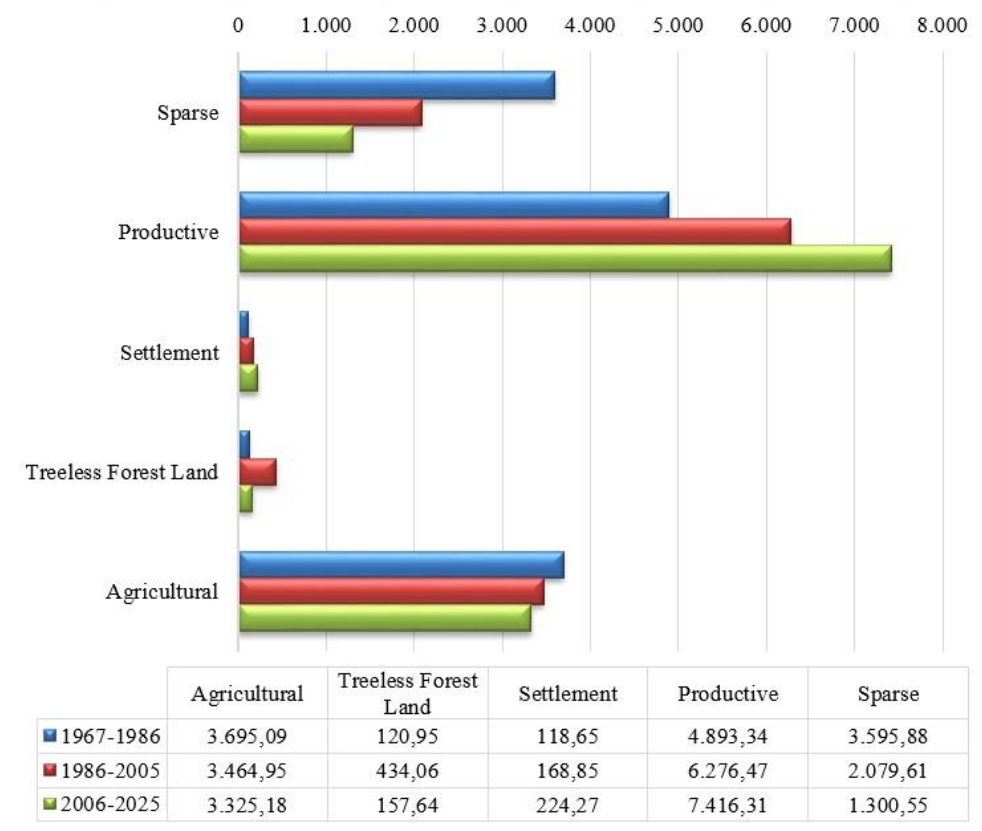

Figure 2. Areal changes of land cover (ha) by planning periods 
Changes in Settlement Land

Measured as 118.65 ha in forest cover type map of 1967 plan, settlement land increased by $42 \%$ in 1986 and reached 168.85 ha. By 2006 , it increased by $33 \%$ to 224.27 ha. Settlement land increased by $89 \%$ in a period of 40 years (Figure 2).

\section{Changes in Treeless Forest Land (TFL)}

Forest lands without tree canopy (TFL) were identified to be 120.95 ha in 1967 , increasing approximately by $\% 259$ to 434.06 ha in 1986 (Figure 2). The TFL land of 434.06 ha decreased by $\% 64$ to 157.64 ha in 2006 . At the end of the period of 40 years, an increase of $30 \%$ in TFL lands was observed.

\section{Changes in Agricultural Land}

It was found that the agricultural land of $3,695.09$ ha in 1967 decreased by $6 \%$ to
(230.14) in 1986 to 3,464.95 (Figure 2). Compared to previous planning period, it was determined that agricultural land decreased by $4 \%$ (139.77) to $3,325.18$ ha in 2006 . Over the course of 40 years from the inception of planned period 1967 to 2006, agricultural lands decreased by 10\% (369.91 ha).

\section{Areal Changes by Tree Species}

As a result of planning studies carried out during the 1967-1986 planning period, it was determined that there were 37 types of stands in the planning unit. Dominant tree species data for stands covering productive forest lands are given in Figure 3. Stands dominated by Fagus rank first with 3,805.32 ha; Oak second with 455.59 ha; Fir third by 373.66 ha; and lastly Black Pine fourth with 258.77 ha (Figure 3).

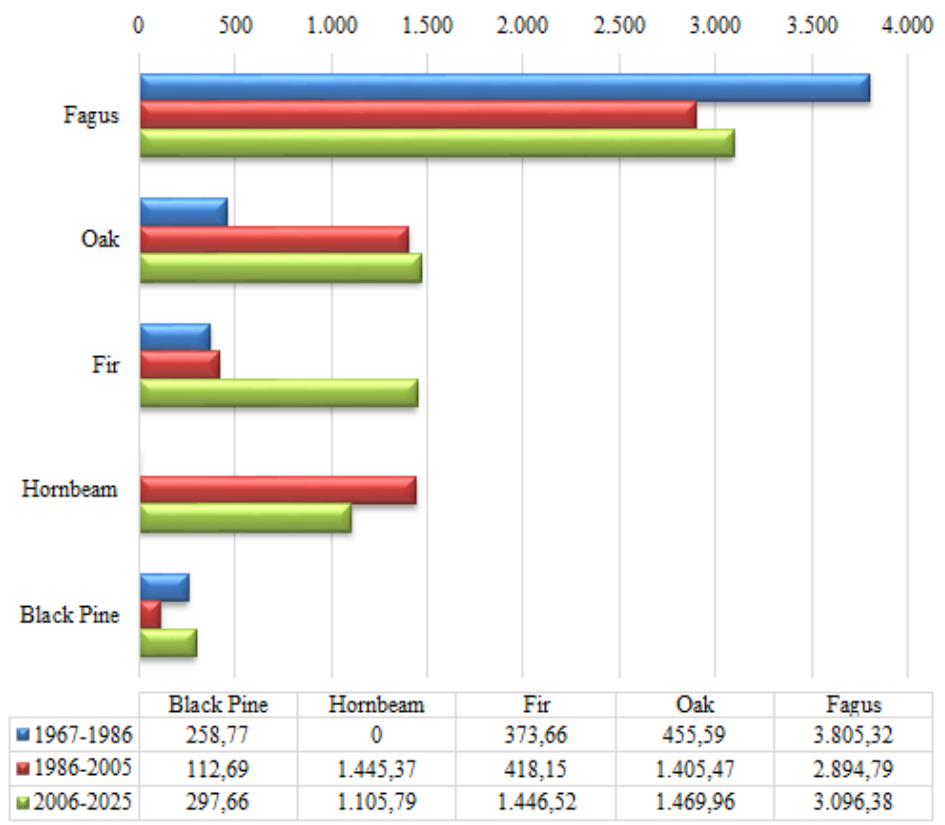

Figure 3. Areal changes of tree species (ha) by planning periods

A total of 74 stands were segregated based on stand type segregation performed for the planning period of 1986-2005. According to the results, Fagus remained first with the most increase of 2,894.79. Undetected in the previous planning period but revealed in this planning period, Hornbeam ranks second with 1,445.37 ha. Oak ranks third with 1,405.47 ha; Fir fourth with 418.15 ha; whereas Black Pine fifth with 112.69 ha (Figure 3). Coppices being considered in 1967 as unproductive forest lands can be the actual reason of this dramatic increase in Hornbeam and Oak in 1986.

According to the results, it is understood that in the 1967-1986 management plan period, Hornbeam and Oak species predominate coppices included in rehabilitation areas. According to the planning in 2005 for the 2006-2025 planning period, 68 
stands were segregated. Stands dominated by Fagus in the planning period of 2006-2025 rank first with 3,096.38 ha of land. Oak ranks second with 1,469.96 ha; Fir third with 1,446.52; Hornbeam fourth with $1,105.79$ ha; and Black Pine fifth with 297.66 ha (Figure 3).

The only tree species with its area decreased in a period of 40 years is Fagus. A decline amount of 708.94 ha was found between Fagus' 1967 and 2006 areas. It was determined that the highest increase of areas was seen in Hornbeam, Fir, and Oak, respectively. The impact of main factors such as growing environment, general characteristics of the species, types and severities of silvicultural interventions are strong in qualitative and quantitative changes in stand types. In addition, the influence of changes in the techniques and methods used during the inventory studies in the relevant regulations is also remarkable in each year.

\section{Areal Changes by Development Stages}

Within the framework of an evaluation of 40 years, areas in a, c, and d development stages had a continuous increase. Stands in development stage b with an area of 4,828.97 ha only in 1967 decreased by $24 \%$ to $3,664.66$ ha (Figure 4). As seen in Figure 2, despite productive forest land measured as $6,276.47$ for the period of 1986-2005, productive forest land measured as 6,279.86 ha under this title that investigates development stages. The observed difference of 3.39 ha area from the fact that Kna stand does not create canopy closure and therefore is not included in sparse forest land class.

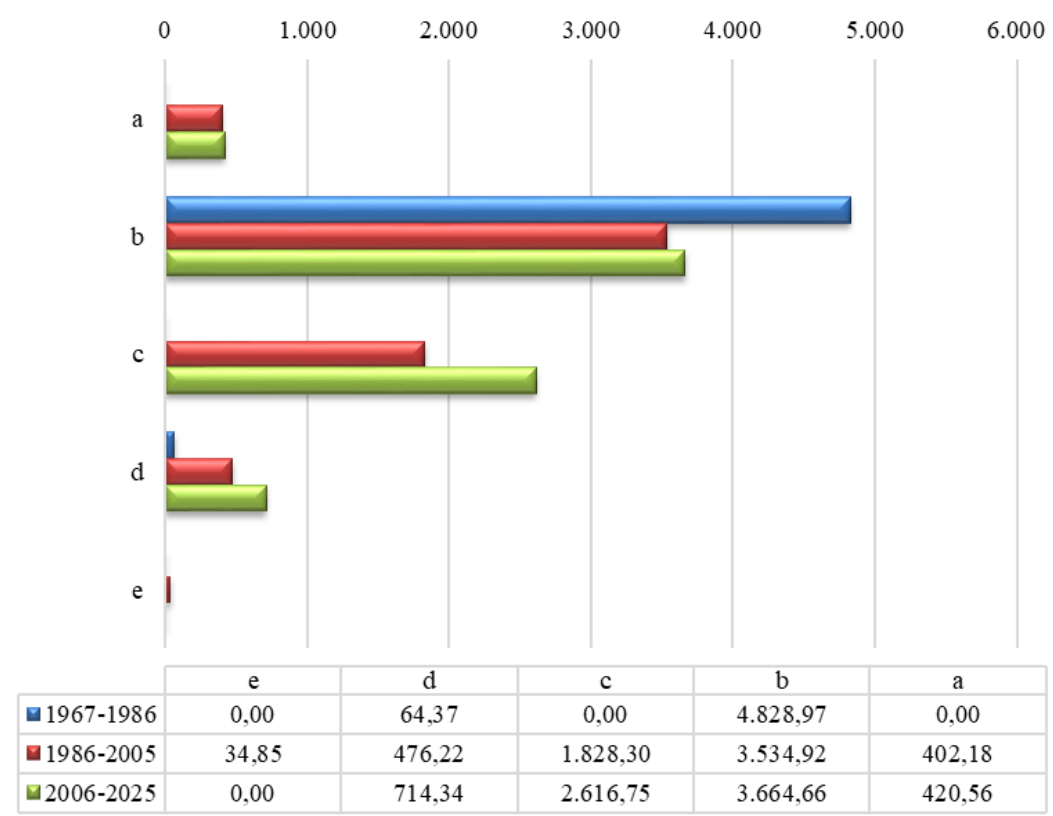

Figure 4. Areal changes of development stages (ha) by planning years

A certain degree of difference was observed in development stage classification within forest management plan for the years 1967-1986 compared to other periods. Based on diameter at breast-height $\left(\mathrm{DBH}, \mathrm{d}_{1,3}\right)$ in the plan development stages were evaluated as follows:

- $\quad 0$ to $9.9 \mathrm{~cm}$ (a development stage)

- $\quad 10$ to $35.9 \mathrm{~cm}$ (b development stage)

- $\quad$ over $36 \mathrm{~cm}$ (d development stage).
In the previous segregation of development stages, stage $\mathrm{c}$ that is within 20 to $35.9 \mathrm{~cm}$ range was classified under stage $\mathrm{b}$ $(b+c)$ in 1967. Stands in stage e, only seen in 1986 plan, were not found in 2006 plan. There are two reasons for this. First reason is the inclusion of $36 \mathrm{~cm}$ and DBH with bark into development stage $\mathrm{d}$ rather than separating diameters of 36 to $51.9 \mathrm{~cm}$ and over $52 \mathrm{~cm}$ during inventory studies, whereas the second 
reason is the absence of trees with higher diameters from the field in accordance with management plans and policies over time.

Areal Changes in Degrees of Canopy Closure Investigating areal changes in degrees of canopy closure within the planning period reveals that stands with type 3 (71-100\% canopy closure) decreased by $15 \%$ from $3,317.93$ ha in 1967 to $2,793.26$ ha in 1986 , meanwhile increasing by approximately
$147 \%$ in 2006 to $6,893.24$ ha. At the end of the period of 40 years, stands with type 3 increased by $108 \%$ (Figure 5).

Area of type 2 (41-70\% canopy closure) stands was determined to be $3,192.89$ ha with an increase of $102 \%$ in 1986. Area of this type of stand decreased by $88 \%$ down to 368.54 ha according to the results from 2006 plan inventory. Over the course 40 years, stands of type 2 decreased generally by $77 \%$.

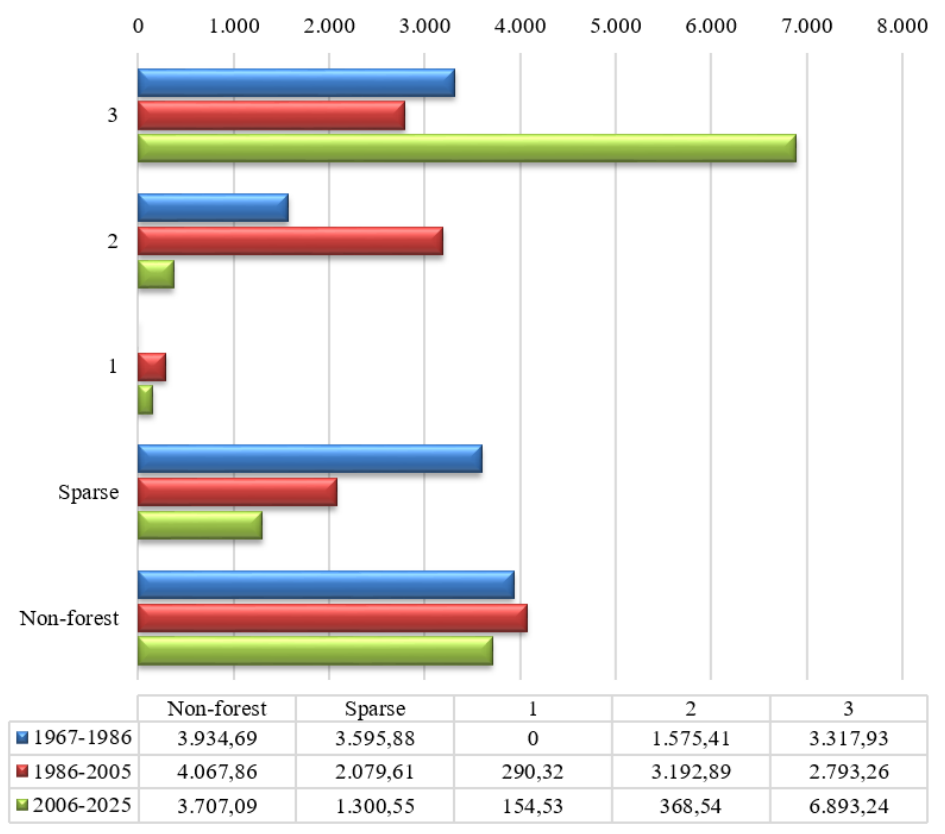

Figure 5. Areal changes of degrees of canopy closure (ha) by planning years

It is not possible to see any stands of type 1 (11-40\% canopy closure) in 1967. Such stands had an area of 290.32 ha in 1986, decreasing comparably by $47 \%$ to 154.53 ha in 2006.

Productive forest stands with type 3 canopy closure, increased by $104 \%$ in 40 years, and those of sparse (with less than $10 \%$ canopy closure) decreased by $64 \%$ whereas non-forest land (settlement, agricultural and treeless forest lands) 6\%. Similarly in Aydoğan FSD of Boyabat FOD of Kastamonu $\mathrm{RDF}$, an increase was observed in stands of type 3 in constrast to a decrease in those of type 2 ; whereas no remarkable change was observed in stands of type 1 density (Kanja and Karahalil, 2015).

\section{Discussion and Conclusion}

According to the evaluation through results of the study, it was found that there was an increase of 227.6 ha in forest land in addition to a decrease of 227.6 ha in non-forest land between 1967 and 2006. Further, an increase of 2,523 ha $(52 \%)$ in productive forest land compared to a decrease of 2,295.33 ha (64\%) in sparse forest land was also discovered. Investigating 2017 country-wise forestry statistics on forest lands in Turkey, an increase of $43 \%$ in productive forest land in contrast with a decrease of $15 \%$ in sparse forest land from 1973 through 2015 was observed (GDF, $2017 b$ ). Increase ratios in productive forest land and decrease ratios in sparse forest land are above the average compared to the rest of Turkey. A decrease of $6 \%$ revealed itself in non-forest land in the field of the study from 
1967 through 2006. In addition, a decrease of 369.91 ha in agricultural land in contrast with an increase of 36.69 ha in treeless forest land (TFL) and of 105.62 ha in settlement land were observed as well in non-forest lands.

It is true that a number of economic, ecological, and social factors play a role in temporal and spatial changes observed. Immigration from rural to urban areas accelerating after the $80 \mathrm{~s}$ in the local region can be defined as the primary reason of increases in forest land and decreases in agricultural land within the field of this study. Populations of forest villages in the district of Ulus display a dramatic decrease of $64.64 \%$ in accordance with district-based average population flows of forest villages at the province of Bartın for the years between 1960 and 2010. Such a value indicates that forest villages of the district of Ulus have the highest decrease among forest villages at the province of Bartın (Günşen, 2012). Decreased population and increased levels of income in forest villages further brought decreasing pressure on firewood and dependence on forest resources primarily, while increasing forest lands (Alkan, 2014). Agricultural land previously reclaimed from forest lands in an uncontrolled manner started to re-grow the forest canopy for not being cultivated over time due to decreasing population. Besides, factors such as successful implementation of rehabilitation activities to rehabilite sparse forests and forestation activities by the forestry authority as well as legal, technical, and scientific protection of forest lands all played a significant role on recent increases in the areas of forest land.

It is critically necessary to protect, expand, and track the production capacity, quality, biodiversity, contribution to global carbon cycle, water and soil resources, and socioeconomic function of the forest ecosystem for sustainable management and operation of forests. For this reason, it is very important to monitor report and take necessary precautions in place and on time in forest ecosystems.

Turkish forestry authority supervised technology and scientific developments in the field, which it has always followed closely with achievements of healthier and safer forest management plans successfully rendered into implementation. In recent years,
GIS and remote sensing methods have been used effectively, both by the forestry authority and by many researchers in forestry. In this way, more reliable and realistic analysis of the past of the forest land as well as more accurate forecasts for the future can be made by determining the actual conditions and healthy decisions to be taken. In addition, spatial and temporal changes occurring in forest lands can be displayed in a more economic and rational manner and reported easily.

This and similar studies in which the change of forest and non-forest lands within a plan unit are investigated under various categories, there is still to be done in other planning units of Turkey. Thus, it is necessary to lay out hierarchical changes starting from forestry subdistrict directorates to forest operation directorates as well as regional directorates of forestry, and ultimately the whole country, in addition to presenting reasons for these changes. The resulting data will contribute to the establishment of a healthier data archive for the future, especially in multiple areas such as forest management plans, biodiversity, carbon stock capacities as well as calculation of rates.

\section{Acknowledgement}

We would like to thank Zonguldak Regional Directorate of Forestry and Ulus Forest Operation Directorate and their staff for supplying and delivering forest cover type maps and forest management plans.

\section{References}

Alkan, S. (2014). Kırsal nüfus değişiminin, ormanlar ve ormancillk üzerine etkileri (Trabzon ili örneği). Kastamonu Üniversitesi Orman Fakültesi Dergisi, 14(1), 69-78.

Asan, Ü. (2017). Orman Amenajmanı (Planlama Sistemleri). İstanbul Üniversitesi Orman Fakültesi, İstanbul Üniversitesi Yayın No: 5227, Fakülte Yayın No: 513, ISBN: 978-60507-0617-8, İstanbul: Yazın Basın Yayın Matbaacilık.

Çakır, G., Ün, C., Başkent, E.Z., Köse, S., Sivrikaya, F. \& Keleş, S. (2008). Evaluating urbanization, fragmentation and land use/land cover change pattern in Istanbul city, Turkey from 1971 to 2002. Land Degradation \& Development, 19(6), 663-675.

DeFries, R. S., Field, C. B., Fung, I., Collatz, G. J. \& Bounoua, L. (1999). Combining satellite 
data and biogeochemical models to estimate global effects of human-induced land cover change on carbon emissions and primary productivity. Global Biogeochemical Cycles, 13(3), 803-815.

Dixon, R.K., Solomon, A.M., Brown, S., Houghton, R.A., Trexier, M.C. \& Wisniewski, J. (1994). Carbon pools and flux of global forest ecosystems. Science, 263(5144), 185190.

Durkaya, B., Varol, T. \& Durkaya, A. (2014). Determination of carbon stock changes: biomass models or biomass expansion factors. Fresenius Environmental Bulletin, 23(3), 774781.

Durkaya, B., Varol, T. \& Durkaya, A. (2016). Karbon stok ve arazi kullanım değişimleri: Arıt örneği [Öz]. 3rd Annual International Conference on Turkey and Turkish Studies sunulan bildiri, Athens, Greece: Erişim adresi: https://www.atiner.gr/abstracts/2016ABSTTUR.pdf

FAO, (2016). State of the World's Forests 2016. Forests and agriculture: Land-use challenges and opportunities. FAO Report.

Günlü, A., Kadığulları, A.İ., Keleş, S. \& Başkent, E.Z. (2009). Spatiotemporal changes of landscape pattern in response to deforestation in Northeastern Turkey: a case study in Rize. Environmental monitoring and assessment, 148(1-4), 127-137.

Günşen, H.B. (2012). Orman köylerinde iç göçleri etkileyen faktörler (Bartın-Kastamonu Örneği), Doktora Tezi, Bartın Üniversitesi, Fen Bilimleri Enstitüsü, Bartın.

Hayes, D.J. \& Cohen, W.B. (2007). Spatial, spectral and temporal patterns of tropical forest cover change as observed with multiple scales of optical satellite data. Remote Sensing of Environment, 106(1), 1-16.

Kadığulları, A. \& Başkent, E. (2006). Orman kaynaklarının konumsal ve zamansal değişiminin coğrafi bilgi sistemleri ve uzaktan algılama teknikleri ile irdelenmesi: İnayet ve Yenice örneği. Süleyman Demirel Üniversitesi Fen Bilimleri Enstitüsü Dergisi, 10(3), 378390.

Kadıŏulları, A.İ., Keleş, S., Başkent, E.Z. \& Günlü, A. (2008). Spatiotemporal changes in landscape pattern in response to afforestation in Northeastern Turkey: a case study of Torul. Scottish Geographical Journal, 124(4), 259273.

Kadığulları, A.İ. (2012). Tunceli ilinin arazi örtüsünün konumsal ve zamansal değişiminin incelenmesi. Artvin Çoruh Üniversitesi Orman Fakültesi Dergisi, 13(1), 1-12.
Kanja, K. \& Karahalil, U. (2015). Aydoğan Orman İşletme Şefliği orman kaynaklarında meydana gelen zamansal ve konumsal değişimin CBS ve uzaktan algılama yardımıyla ortaya konması, TUFUAB VIII. Teknik Sempozyumu Bildiriler Kitab1, Konya, Cilt I, 369-375.

Karahalil, U., Kadiogullari, A., Başkent, E. \& Köse, S. (2009). The spatiotemporal forest cover changes in Köprülü Canyon National Park (1965-2008) in Turkey. African Journal of Biotechnology, 8(18), 4495-4507.

Kaptan, S. (2018). Sosyo-Ekonomik Durum Envanteri ve Orman Amenajman Planlarına Yansitılması. Doktora Tezi, Bartın Üniversitesi, Fen Bilimleri Enstitüsü, Bartın.

Karaköse, M., Terzioğlu, S., Başkent, E.Z. \& Karahalil, U. (2013). Çamlıhemşin (Rize) orman planlama biriminin habitat tiplerinin tespiti ve konumsal değişimlerinin izlenmesi. Firtına Vadisi Sempozyumu, 25-27.

Keleş, S., Sivrikaya, F., Çakir, G., Başkent, E. Z. \& Köse, S. (2008). Spatial and temporal changes in forest cover in Turkey's Artvin forest, 1972-2002. Polish Journal of Environmental Studies, 17(4).

Keleş, S., Başkent, E.Z. \& Kadıoğulları, A.İ. (2009). Simulation-based forest management planning: a framework. Kastamonu Üniversitesi Orman Fakültesi Dergisi, 9(2), 136-145.

GDF (1967). Forest management plans of Drahna (Drahna serisi orman amenajman planı 19671986). General Directorate of Forestry of Turkey (GDF), District Forest Management Directorate; Orman Bölge Müdürlüğü, Zonguldak, (in Turkish). Ankara: GDF, p 84.

GDF, (2006). Forest management plans of Drahna (Drahna orman amenajman planı 2006-2025). General Directorate of Forestry of Turkey (GDF), District Forest Management Directorate; Orman Bölge Müdürlüğü, Zonguldak, (in Turkish). Ankara: GDF, 374p.

GDF, (2016). Forestry Statistics 2016, https://www.ogm.gov.tr/ekutuphane/Istatistikl er/ (Accessed: 20 June 2018).

GDF, (2017a). Procedures and principles for the application of functional forest management plans based on ecosystem. Ekosistem tabanl fonksiyonel orman amenajman planlarının düzenlenmesine ait usul ve esaslar. (in Turkish).

https://www.ogm.gov.tr/ekutuphane/Tebligler/ Ekosistem\%20Tabanl\%C4\%B1\%20Fonksiyo nel\%20Orman\%20Amenajman\%20Planlar\% C4\%B1n\%C4\%B1n\%20D\%C3\%BCzenlenm esine\%20Ait\%20Usul\%20ve\%20Esaslar.pdf (Accessed: 21 March 2018). 
GDF, (2017b). Forestry Statistics 2017, https://www.ogm.gov.tr/ekutuphane/Istatistikl er/ (Accessed: 20 June 2018).

Özdemir, İ. \& Özkan, U. (2003). Armutlu orman işletme şefliğindeki orman alanlarındaki değişimlerin Landsat uydu görüntüleri kullanılarak izlenmesi. Turkish Journal of Forestry, 1, 55-66.

Turan, S.Ö. \& Günlü, A. (2010). Spatial and temporal dynamics of land use pattern response to urbanization in Kastamonu. African Journal of Biotechnology, 9(5).

Sivrikaya, F., Cakir, G., Kadıŏulları, A.İ., Keleş, S., Başkent, E.Z. \& Terzioğlu, S. (2007). Evaluating land use/land cover changes and fragmentation in the Camili forest planning unit of northeastern Turkey from 1972 to 2005. Land Degradation \& Development, 18(4), 383396.

Terzioğlu, S., Başkent, E.Z., Sivrikaya, F., Çakir, G., Kadığulları, A.İ., Başkaya, Ş. \& Keleş, S. (2010). Monitoring forest plant biodiversity changes and developing conservation strategies: a study from Camili Biosphere Reserve Area in NE Turkey. Biologia, 65(5), 843-852.

Verbesselt, J., Hyndman, R., Newnham, G. \& Culvenor, D. (2010). Detecting trend and seasonal changes in satellite image time series. Remote sensing of Environment, 114(1), 106115.

Yavuz, M. \& Vatandaşlar, C. (2018). Korunan alanlardaki zamansal ve ekolojik değişimin parçalılık analizi yardımıyla izlenmesi: Karagöl-Sahara Milli Parkı örneği. Turkish Journal of Forestry Research, 5(1), 82-96. 